\title{
Measurement of Family and Household Composition in Census 2000: An Update
}

\author{
SteVen RugGles
}

IN A RECENT article, we (Ruggles and Brower 2003) described changes in census measures of household and family composition in the United States since 1850 . Because the article was prepared before the release of microdata from Census 2000, it was incomplete. This note fills gaps in the article and discusses the implications of procedural changes for the measurement of families and households in 2000.

The census concepts of household and group quarters were significantly modified for Census 2000. From the 1930 to the 1990 decennial censuses, the Census Bureau defined group quarters as institutions and other units with more than a specified number of persons unrelated to the householder or household head. In 1980 and 1990, for example, any unit with ten or more unrelated persons was classified as group quarters, and from 1950 to 1970 units with five or more unrelated persons were considered group quarters. Census 2000 does not consider the number of unrelated persons as a basis for classification as group quarters. Instead, the Census Bureau defined group quarters by a long list of specific kinds of units, ranging from "Bureau of Indian Affairs Detention Centers" to "living arrangements for victims of natural disasters" (U.S. Census Bureau 2003). These units were identified in advance of the census as part of a national inventory of "Special Places," carried out principally by telephone (Denise I. Smith, personal communication, 25 June 2003). Notably absent from the Special Places list are boarding and lodging houses; in Census 2000, these are considered regular households, regardless of their size.

The effects of these changes are surprisingly small. Table 1 presents estimates of the number of households and the size of the group-quarters population under the 1950-70 definition (households must have fewer than five nonrelatives), the 1980-2000 definition (households must have fewer than ten nonrelatives), and the new 2000 definition. For practical purposes, the new definition makes little difference. Indeed, the entire 1 percent Census 
TABLE 1 Estimates of the number of households and number of group-quarters (GQ) residents in Census 2000 under alternative group-quarters definitions

\begin{tabular}{lll}
\hline GQ definition & Number of households & $\begin{array}{l}\text { Number of noninstitutional } \\
\text { GQ residents }\end{array}$ \\
\hline $1950-70^{\mathbf{a}}$ & $105,393,669$ & $3,103,979$ \\
$1980-90^{\mathbf{b}}$ & $105,476,001$ & $3,686,232$ \\
$2000^{\mathrm{c}}$ & $105,480,101$ & $3,719,594$ \\
\hline
\end{tabular}

annits with five or more persons unrelated to the head are classified as group quarters.

bunits with ten or more persons unrelated to the head are classified as group quarters.

'Based on a detailed list of group-quarters types. See text.

SOURCE: Ruggles and Sobek 2003.

2000 microdata sample includes only 42 households that would have been classified as group quarters in 1980 or 1990 because of their large number of unrelated persons.

Several of these households are composed exclusively of college students, including one unit with 53 female housemates aged 18 to 24 , all of whom were attending a public university. Other units are composed entirely of farm laborers or construction laborers. It is possible that some of these units should have been classified as group quarters under the Census 2000 definitions but were classified as households inadvertently. If a groupquarters unit was missed by the Special Places inventory, it received a regular household form and would therefore be classified as a household instead of group quarters.

Census 2000 defines rooming and boarding houses as regular households, so the microdata should allow us to examine them as intact units. Surprisingly, however, virtually no boarding or rooming houses actually appear in the Census 2000 microdata. The 1 percent census microdata file includes no units with more than 13 roomers or boarders, and only six units with ten or more roomers or boarders. ${ }^{1}$ Partly, this reflects the long-run decline of such living arrangements. In part, however, the lack of rooming and boarding houses is a result of shifting census definitions. As noted by Ruggles and Brower, changes in the criteria for distinguishing households between 1940 and 1970 meant that hundreds of thousands of single rooms with access to a common hallway began to be classified as independent households instead of as group-quarters residences. ${ }^{2}$

In sum, Census 2000 significantly shifted the concepts of household and group quarters, but the statistical consequences of that shift are minor. Investigators who wish to impose a uniform definition can use the groupquarters variable in the Integrated Public Use Microdata Series (IPUMS), which classifies units in all years according to both the 1950-70 and the 1980-90 household definitions. ${ }^{3}$ 
By itself, however, adoption of consistent thresholds for group-quarters residence is insufficient to ensure long-run comparability in measures of household and family composition. The extraordinarily low frequency of boarding and rooming houses observed in Census 2000 underlines the implications of changes in rules for distinguishing separate households. As detailed by Ruggles and Brower, changes in these rules over the past halfcentury have meant that many persons who would formerly have been classified as boarders or roomers are now enumerated as independent householders. This shift has consequences not only for studies of boarding and single-room-occupancy housing, but also for analyses of such topics as household size, nonfamily householders, and headship rates.

\section{Notes}

1 The census microdata files include almost 20 percent fewer roomers, boarders, and foster children than do the complete-count census data from Summary File 1, perhaps suggesting that long-form nonresponse was higher than short-form nonresponse for rooming and boarding houses.

2 There was one more definitional change in Census 2000. In 1980 and 1990, separate living quarters were defined as places in which

the residents "live and eat separately from others and [have] direct access to [a] common hall." In Census 2000, the words "and eat" were dropped from the definition. It is doubtful whether this change has significant implications for the interpretation of data, since the census form and instructions have not mentioned eating arrangements since 1960 .

3 IPUMS data are available at http:// ipums.org.

\section{References}

Ruggles, Steven and Susan Brower. 2003. "Measurement of household and family composition in the United States, 1850-2000," Population and Development Review 29(1): 73101 .

Ruggles, Steven and Matthew Sobek. 2003. Integrated Public Use Microdata Series: Version 3.0. Minneapolis: Minnesota Population Center, University of Minnesota.

U.S. Census Bureau. 2003. Census 2000 Summary File 1 Technical Documentation. SF1/11 (April 2003). Accessed at http://www.census.gov/prod/cen2000/doc/sf l .pdf on $20 \mathrm{June}$ 2003. 